\title{
STABILISASI TANAH MANYAWANG UNTUK MENINGKATKAN DAYA DUKUNG (CBR) SEBAGAI LAPIS PONDASI PEKERASAN JALAN LUNGKUH LAYANG - BUNTOK
}

\author{
Bambang Raharmadi \\ Pegawai Negeri Sipil \\ Balai Besar Pelaksanaan Jalan Nasional VII \\ Direktorat Jenderal Bina Marga Kementerian Pekerjaan Umum dan Perumahan Rakyat
}

\begin{abstract}
ABSTRAK
Ruas jalan Lungkuh Layang - Buntok sepanjang 64,69 Km merupakan jalan Nasional Poros Tengah yang menghubungkan Ibukota Provinsi Kalimantan Tengah dengan 4 (empat) Kabupaten di daerah aliran sungai Barito yaitu Barito Selatan, Barito Timur, Barito Utara dan Murung Raya. Tidak tersedianya sumberdaya material yang memenuhi syarat untuk pondasi perkerasan jalan menjadi masalah dalam pembangunan ruas jalan ini. Sebagai alternatif, digunakan material lokal yang tersedia disekitar lokasi dusun Manyawang, dengan dilakukan perbaikan sifat-sifat fisik dan mekanik tanah. Metode perbaikan yang digunakan adalah dengan bahan tambah (yaitu semen) agar memenuhi syarat sebagai lapis pondasi. Keberhasilan usaha ini tergantung kepada prosedur, bahan, dan alat yang digunakan.

Prosedur yang dilakukan dalam pengujian ini adalah mencampur bahan tanah lokal dengan variasi kadar semen 5\%, 6\%, 7\%, 8\%, dan 9\% terhadap berat kering tanah berdasarkan Standar Nasional Indonesia (SNI). Untuk mengetahui sifat fisik dan mekanik dilakukan uji terhadap tanah lokal dan campuran tanah-semen berupa pemadatan standar, dan $C B R$ pemeram 3 hari dengan perendaman 4 hari.

Tujuan dari penyusunan makalah ini adalah untuk mengetahui kontribusi semen terhadap nilai $C B R$ untuk meningkatkan mutu tanah lokal agar dapat digunakan sebagai lapis pondasi perkerasan jalan.

Hasil uji material tanah lokal dusun Manyawang terhadap pengujian distribusi ukuran butir memenuhi syarat yang diijinkan untuk digunakan sebagai material stabilisasi tanah semen, termasuk kelompok $C L-M L$ yaitu lanau tak organik, lempung kepasiran dengan plastisitas rendah berdasarkan klasifikasi tanah sistem USCS sedangkan menurut klasifikasi tanah sistem AASHTO termasuk pada kelompok $A-4$ yaitu tanah lempung lanau dengan plastisitas rendah dengan indek plastisitas $6,21 \% \leq 10 \%$ syarat yang ditentukan. Berat isi kering maksimum $\left(\gamma_{\text {dmax }}\right)$ 1,855 $\mathrm{t} / \mathrm{m}^{3}$, kadar air optimum $\left(W_{\text {opt }}\right)$ 13,0 \% dengan daya dukung $\left(C B R_{100}\right) 9,40 \%$. Hasil pengujian lapis pondasi tanah semen didapat kadar semen optimum $\left(P C_{\text {opt }}\right)$ $7 \%$, dengan nilai $C B R_{\text {optimum }} 120 \% \geq 120 \%$ nilai target yang disyarat (Spesifikasi Umum 2010, revisi 3), berat isi kering maksimum $\gamma_{\text {dmax }} 1,864 \mathrm{t} / \mathrm{m}^{3}$ dan kadar air optimum $\left(W_{\text {opt }}\right) 11,60 \%$.
\end{abstract}

Kata Kunci : CBR, tanah lokal, distabilisasi semen, pondasi perkerasan jalan 


\section{PENDAHULUAN}

\section{Latar Belakang}

Jalan sebagai sistem transportasi nasional mempunyai peranan penting terutama dalam mendukung bidang ekonomi, sosial dan budaya serta lingkungan agar tercapai keseimbangan dan pemerataan pembangunan antar daerah, membentuk dan memperkokoh kesatuan nasional, memantapkan pertahanan dan keamanan nasional serta membentuk struktur ruang dalam rangka mewujudkan sasaran pembangunan nasional.

Ruas jalan Lungkuh Layang - Buntok sepanjang 64,890 Km merupakan jalan Nasional Poros Tengah yang menghubungkan Ibukota Provinsi Kalimantan Tengah dengan 4 (empat) Kabupaten di daerah aliran sungai Barito yaitu Barito Selatan, Barito Timur, Barito Utara dan Murung Raya. Dalam pembangunan ruas jalan ini yang menjadi permasalahan tidak tersedianya sumberdaya alam yang memenuhi syarat, terutama batu pecah untuk pondasi perkerasan jalan yang harus didatangkan dari luar daerah, seperti Pelaihari dan Merak atau memanfaatkan material lokal yang tersedia disekitar lokasi jalan tersebut.

Untuk memanfaatkan material lokal perlu dilakukan usaha perbaikan sifat-sifat fisik dan mekanik tanah agar memenuhi persyaratan Spesifikasi Umum 2010 (revisi 3), nilai CBR target adalah $\geq 120 \%$ dengan umur pemeraman 3 hari dan perendaman 4 hari (SNI 03-3438-1994) sebagai lapis pondasi perkerasan. Usaha perbaikan tanah itu disebut stabilisasi tanah dengan cara mekanis atau dengan menambah suatu bahan tambah (semen).

Sebagai alternatif pengganti fungsi lapis pondasi perkerasan batu pecah adalah tanah lokal yang distabilisasi dengan bahan tambahan (semen). Stabilisasi dengan bahan tambah akan memperbaiki sifat teknis tanah, seperti kekuatan dan plastisitas (Hardiyatmo, 2010)

Dengan menggunakan stabilisasi tanah lokal dengan semen ini di harapkan dapat membantu mengatasi salah satu permasalah dalam pembangunan ruas jalan Lungkuh Layang Buntok.

\section{Perumusan Masalah}

Penelitian ini lebih di fokuskan untuk untuk mengetahui Seberapa besar pengaruh semen terhadap nilai $C B R$ untuk meningkatkan mutu tanah lokal agar bisa digunakan sebagai lapis pondasi perkerasan jalan

\section{Tujuan}

Tujuan dari penyusunan penelitian ini adalah :

a. Untuk mengetahui klasifikasi tanah lokal menurut Unified Soil Classification System (USCS), American Association of State Highway and Transportation Official (AASHTO), ukuran butiran dan batas-batas Atterberg agar bisa digunakan sebagai bahan stabilisasi semen

b. Untuk mengetahui kontribusi semen terhadap nilai $C B R$ untuk meningkatkan mutu tanah lokal agar dapat digunakan sebagai pengganti lapis pondasi perkerasan jalan

c. Untuk mengetahui kadar semen optimum terhadap nilai $C B R$.

\section{Manfaat}

Dengan melakukan penyusunan penelitian ini diharapkan dapat bermanfaat dan berguna, baik secara teoritis maupun praktis, yaitu:

a. Secara teoritis

1. Mengetahui pengaruh penambahan semen pada stabilisasi tanah dengan variasi kadar semen $5 \%, 6 \%, 7 \%, 8 \%$ dan $9 \%$.

2. Menambah pengetahuan tentang lapis pondasi tanah semen di Paket Pembangunan Jalan Lungkuh Layang - Buntok.

3. Menambah bahan rujukan yang dapat dijadikan referensi lebih lanjut.

b. Secara praktis

1. Hasil penyusunan penelitian ini diharapkan dapat bermanfaat di Paket Pembangunan Jalan Lungkuh Layang - Buntok dan sebagai bahan pertimbangan pekerjaan selanjutnya.

2. Sebagai alternatif bahan pengganti lapis pondasi batu pecah sebagai bahan perkerasan jalan yang mungkin dapat lebih menguntungkan dari segi konstruksi dan waktu disekitar ruas jalan Lungkuh Layang - Buntok.

\section{KAJIAN PUSTAKA}

\section{Landasan Teori}

Semen

Semen merupakan bubuk halus yang bila dicampur dengan air akan menjadi ikatan yang akan mengeras, karena terjadi reaksi kimia sehingga membentuk suatu massa yang kuat dan keras, yang disebut hidroulic cement.

Menurut Spesifikasi Umum 2010 (revisi 3), semen yang digunakan untuk Lapis Pondasi Semen 
Tanah adalah semen portland tipe I yang memenuhi ketentuan SNI 15-2049-2004.

Menurut Hardiyatmo, H.C, (2010), SNI 033438-1994 mensyaratkan semen yang digunakan untuk stablisasi semen adalah semen tipe I, sesuai SII-13-1977.

Komposisi kimia dari lima tipe semen tersebut menurut Hawy (1985), dapat dilihat pada Tabel 2.1 berikut :

Tabel 2.1 Presentasi Komposisi Semen Portland

\begin{tabular}{|c|c|c|c|c|c|c|c|c|}
\hline \multirow{2}{*}{$\begin{array}{c}\text { Jenis } \\
\text { Semen }\end{array}$} & \multicolumn{7}{|c|}{ Komposisi Dalam Persen (\%) } & Karakteristik \\
\cline { 2 - 7 } & $\mathrm{C}_{3} \mathrm{~S}$ & $\mathrm{C}_{2} \mathrm{~S}$ & $\mathrm{C}_{3} \mathrm{~A}$ & $\mathrm{C}_{4} \mathrm{AF}$ & $\mathrm{CaSO}_{4}$ & $\mathrm{CaO}$ & $\mathrm{MgO}$ & Umum \\
\hline $\begin{array}{l}\text { Tipe I } \\
\text { Normal }\end{array}$ & 49 & 25 & 12 & 8 & 2,9 & 0,8 & 2,4 & $\begin{array}{l}\text { Semen untuk } \\
\text { semua tujuan }\end{array}$ \\
\hline
\end{tabular}

Sumber : Alizar (2011)

Menurut Mindess dan Young (1981), waktu ikatan yang dibutuhkan untuk terjadinya pengerasan semen pada beton dapat dibagi dua, yaitu:

1. Waktu ikatan awal (initial setting time), yaitu waktu dari saat pertama bercampurnya semen dengan air sampai kehilangan sifat keplastisannya.

2. Waktu ikatan akhir (final setting time), yaitu waktu dari campuran semen dengan air yang telah menjadi pasta, kemudian berubah menjadi masa yang kaku/keras.

Waktu ikatan awal berkisar 1 sampai 2 jam, tidak boleh kurang dari 1 jam setelah pencampuran, dan ikatan akhir tidak boleh lebih dari 8 jam.

Untuk mengetahui waktu ikatan awal dapat juga dengan pengujian menggunakan alat Vicat sesuai dengan SNI. 03-6827-2002

\section{Air}

Air yang digunakan dalam stabilisasi tanahsemen mempunyai dua fungsi, yaitu untuk memungkinkan terjadinya reaksi kimia dengan semen selama proses pengerasan dan sebagai bahan pelumas antara campuran tanah-semen, sehingga memudahkan pelaksanaan.

Pada umumnya, semua jenis air dapat digunakan untuk stabilisasi semen dan air minum termasuk yang paling baik. Akan tetapi, air dengan kandungan organik yang tinggi dapat menyebabkan masalah, sehingga penggunaannya harus dihindari. Hal yang lebih penting, adalah banyaknya air yang diperlukan dalam proses pemadatan, bukan air yang dibutuhkan untuk hidrasi semen (Ingles-Metcalf, 1972). Air yang digunakan dalam pekerjaan haruslah air tawar dan bebas dari endapan maupun larutan atau bahan suspensi yang mungkin dapat merusak pembuatan lapis pondasi tanah semen seperti yang ditentukan dan harus memenuhi ketentuan yang disyaratkan dalan SNI 03-6817-2002 (Spesifikasi Umum 2010, revisi 3).

Menurut Hardiyatmo, H.C, (2010), SNI 033438-1994 mesyaratkan air untuk stabilisasi dengan semen adalah seperti dijelaskan dalam Tabel 2.2 berikut :

Tabel 2.2 Persyaratan Air Untuk Stabilisasi Dengan Semen

\begin{tabular}{|c|l|l|l|}
\hline No. & Jenis Pengujian & \multicolumn{1}{|c|}{ Nilai Yang Diijinkan } & \multicolumn{1}{|c|}{ Metode Pengujian } \\
\hline \hline 1. & PH & $4,5-8,5$ & SNI M03 $-1990-\mathrm{F}$ \\
\hline 2. & Bahan Organik & Maks. 2000 ppm & AASHTO T26-79 \\
\hline 3. & Minyak & $<2 \%$ of cement & SNI M69 -1990-03 \\
\hline 4. & Sulfat.Na2SO4 & $<10000 \mathrm{ppm}$ & SNI 06-2426-1990 \\
\hline 5. & Klorida, NaCl & $<20000 \mathrm{ppm}$ & SNI 06-2421-1991 \\
\hline
\end{tabular}

Sumber: Hardiyatmo (2010)

\section{Tanah}

Tanah sebagai bahan yang terdiri dari agregat mineral-mineral padat yang tidak terikat secara kimia antara satu sama lain dari bahan-bahan organik yang telah melapuk yang berpartikel padat disertai dengan zat cair dan gas yang mengisi ruang-ruang kosong diantara partikel partikel padat tersebut (Das, 2008).

- Pengujian Distribusi Ukuran Butir

Distribusi ukuran butir adalah pengelompokan besar butir analisa agregat kasar dan agregat 
halus menjadi komposisi gabungan yang ditinjau berdasarkan saringan. Menurut Spesifikasi Umum 2010, revisi 3 adalah tanah yang cocok digunakan untuk lapis pondasi semen tanah harus sesuai dengan ukuran partikel yang ditentukan yaitu ukuran yang paling besar dari partikel batu harus lebih kecil dari $75 \mathrm{~mm}$ dan kurang dari 50\% melewati saringan No. 200 dengan cara pengayakan basah. Porland Cement Association (1979), mensyaratakan tanah yang distabilisasi dengan semen sebaiknya tanah-tanah berpasir dan berkerikil dengan gradsi ukuran butir seperti pada Tabel 2.3 sebagai berikut :

Tabel 2.3 Gradasi Ukuran Butir Tanah Semen

\begin{tabular}{|ll|c|}
\hline \multicolumn{2}{|c|}{ Ukuran Saringan } & $\begin{array}{c}\text { Persen Berat Yang Lolos Saringan } \\
\text { Lapis Pondasi Semen Tanah }\end{array}$ \\
\hline 2" & $(50,00 \mathrm{~mm})$ & 100 \\
No. 4 & $(4,750 \mathrm{~mm})$ & $\geq 55$ \\
No. 10 & $(2,000 \mathrm{~mm})$ & $\geq 37$ \\
No. 200 & $(0,075 \mathrm{~mm})$ & $10-35$ \\
\hline
\end{tabular}

Sumber : Hardiyatmo (2010)

- Sistem klasifikasi tanah

Sistem Klasifikasi Tanah Berdasarkan Unified Soil Classification System (USCS).

Sistem ini diperkenalkan oleh Cassagrande tahun 1942 yang selanjutnya disempurnakan oleh Unites States Bureau of Reclamation (USBR) tahun 1952. Sistem ini mengelompokkan tanah dalam dua kelompok besar, yaitu:

a. Tanah Berbutir Kasar (coarse-grained-soil), yaitu: tanah kerikil dan pasir dimana kurang dari $50 \%$ berat total contoh tanah lolos saringan nomer 200. Simbol kelompok ini adalah:

$G=$ untuk tanah berkerikil (Gravel)

$S=$ untuk tanah berpasir (sand)

$W=$ untuk tanah bergradasi baik (well graded)

$P=$ untuk tanah bergradasi buruk (poorly graded)

b. Tanah Berbutir Halus (fine-grained-soil), yaitu tanah dimana lebih dari $50 \%$ berat total contoh tanah lolos saringan nomer 200 .

Simbol kelompok ini adalah:

$M=$ untuk lanau (silt) anorganik

$C=$ untuk lempung (clay) anorganik

$O=$ untuk lanau-organik dan lempungorganik

$L=$ plastisitas rendah $(\mathrm{LL}<50$ ) (low plasticity)

$H=$ plastisitas tinggi (LL > 50) (high plasticity)
Prosedur untuk menentukan klasifikasi tanah Sistem Unified (Hardiyatmo, 2006) adalah sebagai berikut:

1. Tentukan apakah tanah berupa butiran halus atau butiran kasar secara visual atau dengan cara menyaringnya dengan saringan nomer 200.

2. Jika tanah berupa butiran kasar:

a. Saring tanah tersebut dan gambarkan grafik distribusi butiran.

b. Tentukan persen butiran lolos saringan no.4. Bila persentase butiran yang lolos kurang dari 50\%, klasifikasikan tanah tersebut sebagai kerikil. Bila persen butiran yang lolos lebih dari 50\%, klasifikasikan sebagai pasir.

c. Tentukan jumlah butiran yang lolos saringan no.200. Jika persentase butiran yang lolos kurang dari 5\%, pertimbangkan bentuk grafik distribusi butiran dengan menghitung $C u$ da $C c$. Jika termasuk bergradasi baik, maka klasifikasikan sebagai $G W$ (bila kerikil) atau $S W$ (bila pasir). Jika termasuk bergradasi buruk, klasifikasikan sebagai $G P$ (bila kerikil) atau $S P$ (bila pasir). Jika persentase butiran tanah yang lolos saringan no. 200 diantara 5 sampai $12 \%$, tanah akan mempunyai simbol dobel dan mempunyai sifat keplastisan ( $G W-G M$, $S W-S M$, dan sebagainya).

d. Jika persentase butiran yang lolos saringan no. 200 lebih besar $12 \%$, harus dilakukan batas-batas Atterberg dengan 
menyingkirkan butiran tanah yang tinggal dalam saringan no. 40. Kemudian, dengan menggunakan diagram plastisitas, ditentukan klasifikasinya $(G M, G C, S M, G M-G C$ atau $S M-S C$ ).

3. Jika tanah berbutir halus:

a. Kerjakan uji batas-batas Atterberg dengan menyingkirkan butiran tanah yang tinggal dalam saringan no. 40. Jika batas cair lebih dari 50\%, klasifikasikan sebagai $H$ (plastisitas tinggi) dan jika kurang dari $50 \%$, klasifikasikan sebagai $L$ (plastisitas rendah).

b. Untuk $H$ (plastisitas tinggi), jika plot batas-batas Atterberg pada grafik plastisitas dibawah garis A, tentukan apakah tanah organik $(\mathrm{OH})$ atau anorganik $(M H)$. Jika plotnya jatuh diatas garis A, klasifikasikan sebagai $\mathrm{CH}$.

c. Untuk $L$ (plastisitas rendah), jika plot batas-batas Atterberg pada grafik plastisitas dibawah garis A dan area yang diarsir, tentukan klasifikasi tanah tersebut sebagai organik $(O L)$ atau anorganik $(M L)$ berdasar warna, bau, atau perubahan batas cair dan batas plastisnya dengan mengeringkannya didalam oven. d. Jika plot batas-batas Atterberg pada grafik plastisitas jatuh pada area yang diarsir, dekat dengan garis $\mathrm{A}$ atau nilai $L L$ sekitar 50, gunakan simbol dobel.

Cara menentukan klasifikasi tanah berdasarkan Unified Soil Classification System seperti pada Tabel 2.4 berikut:

a. Bawah garis $\mathrm{A}$, tentukan apakah tanah organik $(\mathrm{OH})$ atau anorganik $(\mathrm{MH})$. Jika plotnya jatuh diatas garis $\mathrm{A}$, klasifikasikan sebagai $\mathrm{CH}$.

b. Untuk $L$ (plastisitas rendah), jika plot batas-batas Atterberg pada grafik plastisitas dibawah garis A dan area yang diarsir, tentukan klasifikasi tanah tersebut sebagai organik $(O L)$ atau anorganik $(M L)$ berdasar warna, bau, atau perubahan batas cair dan batas plastisnya dengan mengeringkannya didalam oven.

c. Jika plot batas-batas Atterberg pada grafik plastisitas jatuh pada area yang diarsir, dekat dengan garis A atau nilai $L L$ sekitar 50, gunakan simbol dobel.

Cara menentukan klasifikasi tanah berdasarkan Unified Soil Classification System seperti pada Tabel 2.4 berikut :

Tabel 2.4 Klasifikasi Tanah Sistem USCS

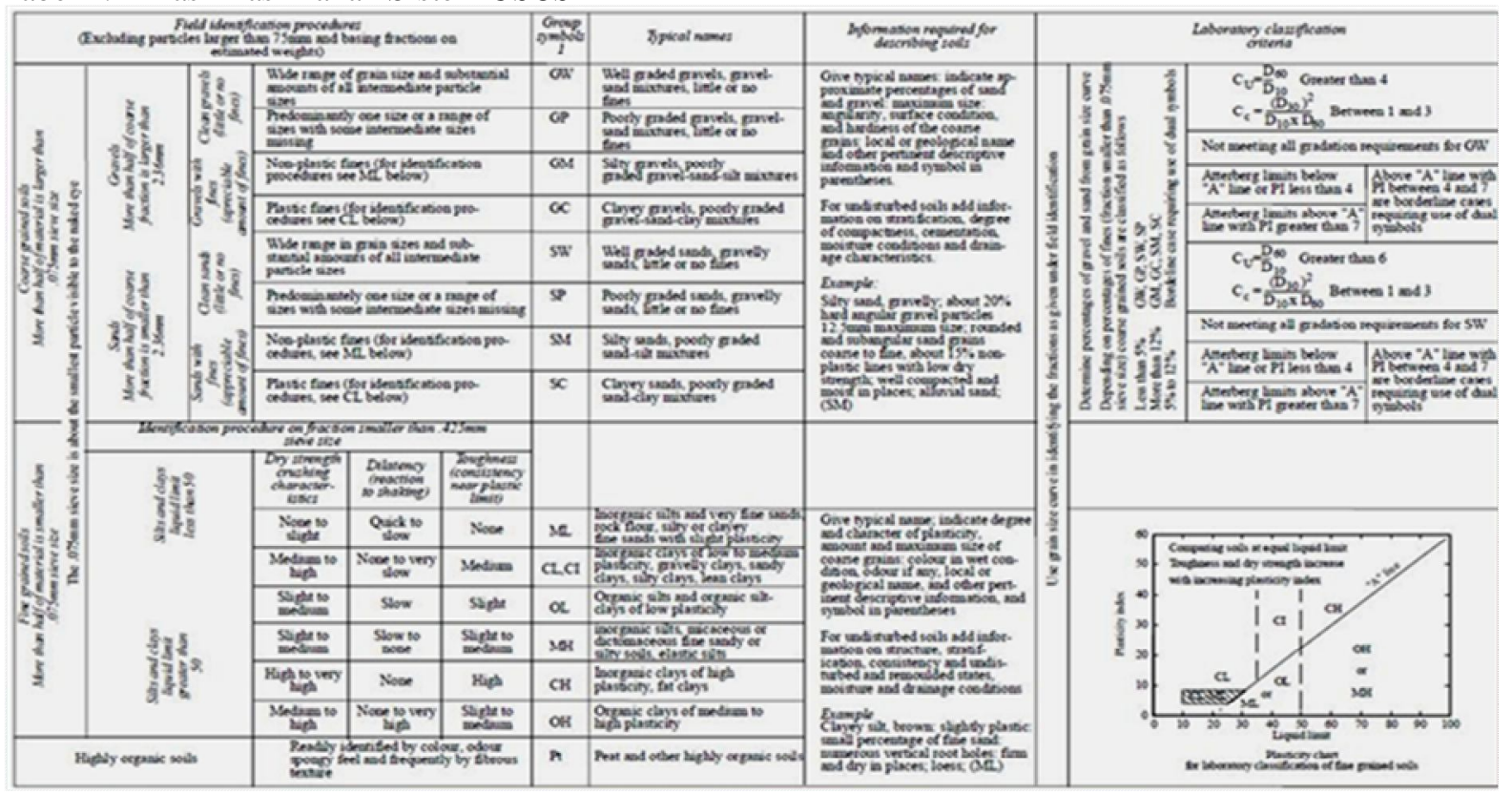

Sumber : Hendarsin (2000) 
Sistem Klasifikasi Tanah American Association of State Highway and Transportation Official (AASHTO).

Sistem klasifikasi AASHTO membagi tanah kedalam 8 kelompok, A-1 sampai A-8 termaksud sub-subkelompok. Tanah-tanah dalam tiap kelompoknya dievaluasi terhadap indeks kelompoknya yang dihitung dengan rumus-rumus empiris.

Pengujian yang digunakan hanya analisis saringan dan batas-batas Atterberg.

Indeks kelompok (group index) digunakan untuk mengevaluasi lebih lanjut tanah-tanah dalam kelompoknya. Indeks kelompok dihitung dengan Persamaan 2.1 berikut :

$$
\begin{aligned}
& G I=(F-35)(0,2+0,005(L L-40)+ \\
& 0,01(F-15)(P I-10)
\end{aligned}
$$

Dengan:

$G I=$ indeks kelompok (group index)

$F=$ persen material lolos saringan no. 200

$L L=$ batas cair

$P I=$ indeks plastisitas

Bila nilai indeks kelompok $(G I)$ semakin tinggi, makin berkurang ketepatan penggunaan tanahnya. Tanah granular diklasifikasikan ke dalam klasifikasi A-1 sampai A-3. tanah A-1 granular yang bergradasi baik, sedang A-3 adalah pasir bersih yang bergradasi buruk.
Tanah A-2 termasuk tanah granular (kurang dari 35\% lewat saringan no. 200), tetapi masih terdiri atas lanau dan lempung. Tanah berbutir halus diklasifikasikan dari A-4 sampai A-7, yaitu tanah lempung-lanau. Perbedaan keduanya berdasarkan pada batas-batas Atterberg seperti pada Gambar 2.1 berikut:

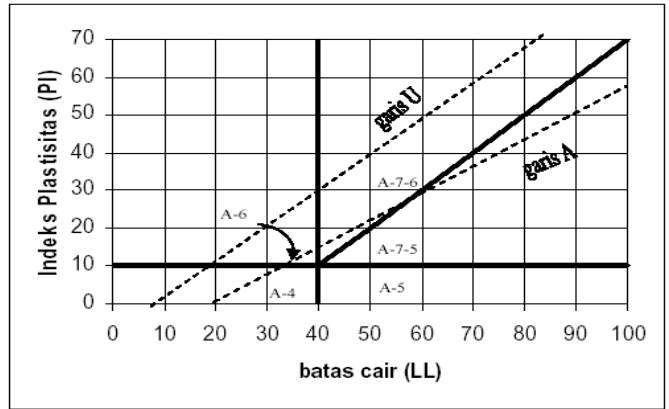

Sumber : Hardiyatmo (1996)

Gambar 2.1 Nilai-nilai Batas-batas Atterberg Untuk Subkelompok A-4, A-5, A-6, dan A-7

- Batas - batas Konsentensi

Batas konsintensi adalah kedudukan fisik tanah berbutir halus pada kadar air tertentu. Konsintensi tergantung pada gaya tarik antara partikel mineral lempung.

Kedudukan batas-batas konsintensi untuk tanah kohesif ditunjukan dalam Gambar 2.2 berikut :

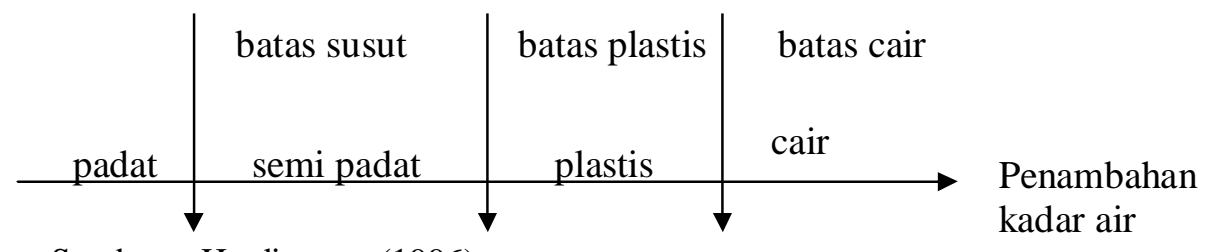

Sumber : Hardiyatmo (1996)

Gambar 2.2 Keadaan-keadaan Konsistensi Tanah

Cara untuk menggambarkan batas-batas konsistensi dari tanah berbutir halus dengan mempertimbangklan kandungan kadar airnya. Batas-batas tersebut yaitu :

a. Batas Cair (Liquid Limit)

Batas cair $(L L)$, didefinisikan sebagai kadar air tanah pada batas antara keadaan cair dan keadaan plastis, yaitu batas atas dari daerah plastis. Porsentase kadar air dibutuhkan untuk menutup celah sepanjang $12,7 \mathrm{~mm}$ pada dasar cawan, sesudah 25 kali pukulan didefinisikan sebagai batas cair tanah tersebut (Hardiyatmo, 1996). b. Batas Plastis (Plastic Limit)

Batas plastis $(P L)$, didefinisikan sebagai kadar air pada kedudukan antara daerah plastis dan semi padat, yaitu persentase kadar air di mana tanah dengan diameter silinder 3,2 mm mulai retak-retak ketika digulung (Hardiyatmo, 1996).

c. Indeks Plastisitas (Plasticity Index)

Indeks plastisitas $(P I)$ adalah selisih batas cair dan batas plastis (Hardiyatmo, 1996) dengan Persamaan 2.2 berikut :

$P I=L L-P L$ 
Indeks plastisitas merupakan interval kadar air dimana tanah masih bersifat plastis.
Batasan mengenai indeks plastis, sifat, macam tanah dan kohesif oleh Atterberg terdapat dalam Tabel 2.7 berikut :

Tabel 2.7 Nilai indeks plastisitas dan macam tanah

\begin{tabular}{|c|l|l|l|}
\hline PI & \multicolumn{1}{|c|}{ Sifat } & \multicolumn{1}{|c|}{ Macam Tanah } & \multicolumn{1}{c|}{ Kohesi } \\
\hline \hline 0 & Non Plastis & Pasir & Non kohesif \\
$<7$ & Plastisitas rendah & Lanau & Kohesif sebagian \\
$7-17$ & Plastisitas rendah & Lempung berlanau & Kohesif \\
$>17$ & Plastisitas tinggi & Lempung & Kohesif \\
\hline
\end{tabular}

Sumber : Hardiyatmo (1996)

Menurut Hicks (2002), distribusi ukuran butir dan batas-batas Atterberg digunakan sebagai dasar penilaian macam stabilisasi yang akan digunakan, seperti yang ditunjukkan pada Tabel 2.8 berikut:

Tabel 2.8 Petunjuk Awal Untuk Pemilihan Metode Stabilisasi.

\begin{tabular}{|c|c|c|c|c|c|c|}
\hline $\begin{array}{l}\text { Material lolos } \\
\text { Saringan no.200 }\end{array}$ & \multicolumn{3}{|c|}{$\begin{array}{l}>25 \% \text { lolos saringan } \\
\text { No. } 200(0,075 \mathrm{~mm})\end{array}$} & \multicolumn{3}{|c|}{$\begin{array}{c}<25 \% \text { lolos saringan } \\
\text { No. } 200(0,075 \mathrm{~mm})\end{array}$} \\
\hline $\begin{array}{c}\text { Indeks } \\
\text { Plastisitas } \\
P I(\%)\end{array}$ & $\leq 10$ & $10-20$ & $\geq 20$ & $\begin{array}{c}\leq 6(P I x \\
\text { persen lolos } \\
\text { saringan } \\
\text { no. } 200 \leq 6)\end{array}$ & $\leq 10$ & $\geq 10$ \\
\hline \multicolumn{7}{|c|}{ Bentuk stabilisasi : } \\
\hline $\begin{array}{l}\text { Semen dan } \\
\text { campuran } \\
\text { pengikat }\end{array}$ & Cocok & Ragu & $\begin{array}{l}\text { Tidak } \\
\text { cocok }\end{array}$ & Cocok & Cocok & Cocok \\
\hline Kapur & Ragu & Cocok & Cocok & $\begin{array}{l}\text { Tidak } \\
\text { Cocok }\end{array}$ & Ragu & Cocok \\
\hline Aspal (bitumen) & Cocok & Ragu & $\begin{array}{l}\text { Tidak } \\
\text { cocok }\end{array}$ & Cocok & Cocok & Ragu \\
\hline $\begin{array}{l}\text { Aspal/semen } \\
\text { dicampur }\end{array}$ & Cocok & Ragu & $\begin{array}{l}\text { Tidak } \\
\text { cocok }\end{array}$ & Cocok & Cocok & Ragu \\
\hline Granular & Cocok & $\begin{array}{l}\text { Tidak } \\
\text { cocok }\end{array}$ & $\begin{array}{l}\text { Tidak } \\
\text { cocok }\end{array}$ & $\begin{array}{l}\text { Tidak } \\
\text { Cocok }\end{array}$ & Cocok & Ragu \\
\hline $\begin{array}{l}\text { Lain-lain } \\
\text { campuran }\end{array}$ & $\begin{array}{l}\text { Tidak } \\
\text { cocok }\end{array}$ & Cocok & Cocok & $\begin{array}{l}\text { Tidak } \\
\text { Cocok }\end{array}$ & Ragu & Cocok \\
\hline
\end{tabular}

Sumber : Hardiyatmo ( 2010)

Petunjuk dari Tabel 2.8 hanya sebagai pertimbangan awal, dan dapat digunakan untuk maksud modifikasi tanah, seperti: stabilisasi dengan kapur untuk membuat material lebih kering dan mengurangi plastisitasnya.

\section{Lapis Pondasi Tanah Semen}

Lapis Pondasi Tanah Semen adalah lapis pondasi yang terbuat dari tanah yang distabilisasi dengan semen. Menurut Manual Konstruksi dan Bangunan Lapis Pondasi Tanah Semen (2006), stabilisasi tanah dengan semen adalah campuran tanah dengan semen dan air dengan komposisi tertentu sehingga tanah tersebut memeliki sifat atau daya dukung yang lebih baik dari semula. Hardiyatmo (2010), Stabilisasi dengan menggunakan bahan tambah atau sering juga disebut stabilisasi kimiawi bertujuan untuk memperbaiki sifat-sifat teknis tanah, dengan cara mencampur tanah dengan menggunakan bahan tambah dengan perbandingan tertentu.

- Pengujian Pemadatan Ringan di Laboratorium Pemadatan adalah suatu proses memadatnya partikel tanah sehingga terjadi pengurangan volume udara dan volume air dengan memakai 
cara mekanis. Kepadatan tanah tergantung banyaknya kadar air, jika kadar air tanah sedikit maka tanah akan keras begitu pula sebaliknya bila kadar air banyak maka tanah akan menjadi lunak atau cair. Pemadatan yang dilakukan pada saat kadar air lebih tinggi daripada kadar air optimumnya akan memberikan pengaruh terhadap sifat tanah. Tujuan pemadatan tanah adalah memadatkan tanah pada kadar air optimum dan memperbaiki karakteristik mekanisme tanah. Maksud pemadatan tanah (Hardiyatmo, 1996) adalah sebagai berikut:

a. Mempertinggi kuat geser tanah.

b. Mengurangi sifat mudah mampat (kompresibilitas).

c. Mengurangi permeabilitas.

d. Mengurangi perubahan volume sebagai akibat perubahan kadar air.

Pemadatan tanah dapat dilaksanakan di lapangan maupun di laboratorium. Dilapangan biasanya tanah akan digilas dengan mesin penggilas yang didalamnya terdapat alat penggetar, getaran akan menggetarkan tanah sehingga terjadi pemadatan. Sedangkan dilaboratorium menggunakan pengujian ringan (standart), yang disebut dengan uji Proctor, dengan cara suatu palu dijatuhkan dari ketinggian tertentu beberapa lapisan tanah di dalam sebuah mold. Dengan dilakukannya pengujian pemadatan tanah ini, maka akan terdapat hubungan antara kadar air dengan berat volume. Derajat kepadatan tanah diukur dari berat volume keringnya, hubungan berat volume kering $\left(\gamma_{d}\right)$, berat volume basah $\left(\gamma_{b}\right)$ dan kadar air $(w)$ dinyatakan dengan Persamaan 2.3 dan Gambar 2.3 berikut :

$\gamma_{d}=\frac{\gamma_{b}}{1+w}$

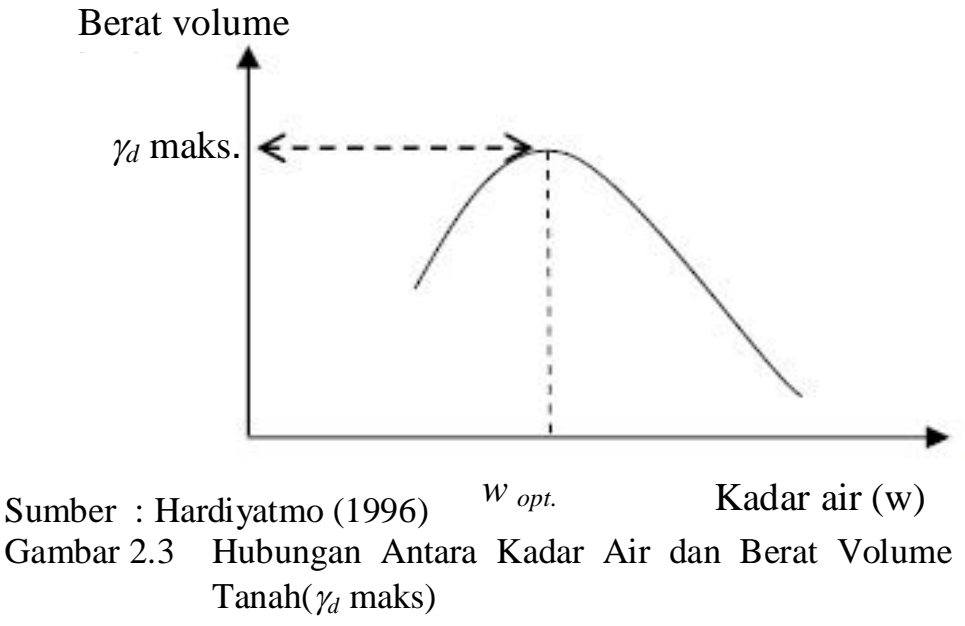

Untuk mengetahui kadar air yang optimum pada tanah, maka dilakukan pengujian pemadatan, pengujian tersebut dilakukan dengan pemadatan sampel tanah basah (pada kadar air terkontrol) dalam suatu cetakan dengan jumlah lapisan tertentu. Setiap lapisan dipadatkan dengan sejumlah tumbukan yang ditentukan dengan penumbuk dengan massa dan tinggi jatuh tertentu. Apabila diketahui berat tanah basah didalam cetakan yang volumenya diketahui, maka berat isi basah dapat langsung dihitung dengan Persamaan 2.4 berikut :

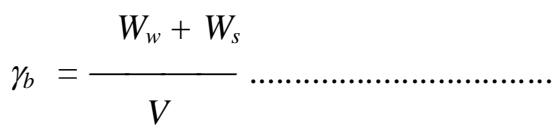

$\gamma$ basah adalah perbandingan berat tanah basah dalam cetakan dengan volume cetakan, kadar air diperoleh dari tanah yang dipadatkan. Untuk tanah berbutir halus dalam mendapatkan kadar air optimum digunakan batas plastisnya. Buat kurva hubungan antara kadar air $(w)$ sebagai absis dan berat volume tanah kering sebagai ordinat, puncak kurva sebagai nilai $\gamma_{d}$ (maksimun), kurva yang digunakan adalah kurva dari uji pemadatan tanah (Proctor). Dari titik puncak dit ditarik garis vertikal memotong absis, pada titik ini adalah kadar air optimum seperti pada Gambar 2.5 berikut :

Berat volume kering

Media Ilmiah Teknik Sipil, Volume 5, Nomor 1, Desember 2016: 15-29 


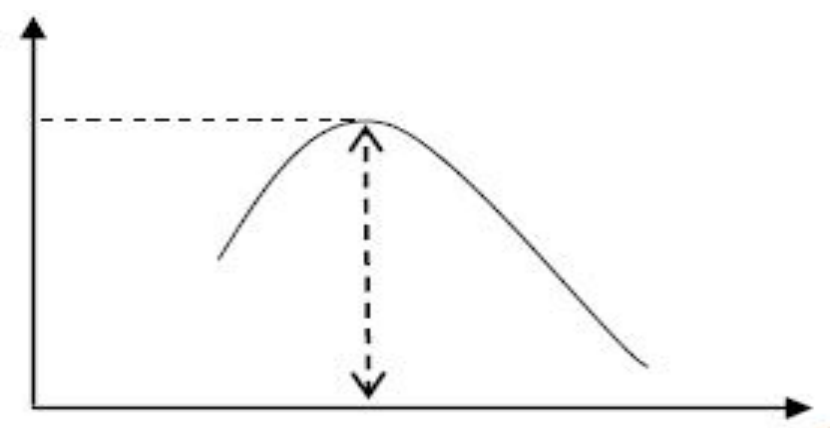

Sumber : Hardiyatmo (1996)

Gambar 2.5 Hubungan Antara Kadar Air dan Berat Volume Tanah (kadar air optimum)

- Uji California Bearing Ratio (CBR)

Nilai CBR adalah perbandingan (dalam persen) antara tekanan yang diperlukan untuk menembus tanah dengan piston berpenampang bulat seluas 3 inch dengan kecepatan 0,05 inch/menit terhadap tekanan yang diperlukan untuk menembus bahan standard tertentu. Untuk menentukan kekuatan lapisan tanah dasar dengan cara percobaan $C B R$ diperoleh nilai yang kemudian dipakai untuk menentukan tebal perkerasan yang diperlukan di atas lapisan yang nilai $C B R$ nya tertentu. Dalam menguji nilai $C B R$ tanah dapat dilakukan di laboratorium. Tanah dasar (Subgrade) pada kontruksi jalan baru merupakan tanah asli, tanah timbunan, atau tanah galian yang sudah dipadatkan sampai mencapai kepadatan 95\% dari kepadatan maksimum. Dengan demikian daya dukung tanah dasar tersebut merupakan nilai kemampuan lapisan tanah memikul beban setelah tersebut tanah dipadatkan. $C B R$ ini disebut $C B R$ rencana titik dan karena disiapkan di laboratorium, disebut $C B R$ laborataorium. Makin tinggi nilai $C B R$ tanah (subgrade) maka lapisan perkerasan diatasnya akan semakin tipis dan semakin kecil nilai $C B R$ (daya dukung tanah rendah), maka akan semakin tebal lapisan perkerasan di atasnya sesuai beban yang akan dipikulnya.

Ada 2 macam pengukuran $C B R$ yaitu :

1. Nilai $C B R$ untuk penekanan pada penetrasi $0,254(0,1$ ") terhadap penetrasi standar yang besarnya $70,37 \mathrm{~kg} / \mathrm{cm}^{2}$ (1000 psi) dengan Persamaan 2.6 berikut :

$$
C B R=\frac{P_{1}}{70,37} \times 100 \%\left(\mathrm{~kg} / \mathrm{cm}^{2}\right) \ldots . .
$$

2 Nilai $C B R$ untuk tekanan pada penetrasi $0,508(0,2 ")$ terhadap tekanan standar yang besarnya $105,56 \mathrm{~kg} / \mathrm{cm}^{2}$ (1500 psi) dengan Persamaan 2.7 berikut:

$$
C B R=\frac{P_{2}}{105,56} \quad \mathrm{x} 100 \%\left(\mathrm{~kg} / \mathrm{cm}^{2} \ldots . .\right.
$$

Nilai $C B R$ untuk lapis pondasi tanah semen disyaratkan (Spesifikasi Umum 2010, revisi 3), seperti ditunjukkan didalam Tabel 2.9 berikut :

Tabel 2.9 Kriteria Kekuatan Lapis Pondasi Tanah Semen

\begin{tabular}{|c|c|c|c|c|}
\hline \multirow{2}{*}{ Pengujian } & \multicolumn{2}{|c|}{ Batas-batas sifat (setelah perawatan 7 hari) } & \multirow{2}{*}{$\begin{array}{c}\text { Metode } \\
\text { Pengujian }\end{array}$} \\
\cline { 2 - 4 } & Min. & Target & Mak. & SNI 1774:2012 \\
\hline CBR (\%) & 100 & 120 & 200 & \multicolumn{2}{|c}{} \\
\hline
\end{tabular}

Sumber : Spesifikasi Umum 2010, revisi 3

\section{Studi Pustaka}

Penelitian-penelitian tentang stabilisasi tanah semen telah banyak dilakukan sebelumnya lainya, seperti yang dilakukan oleh:

a. Bambang R (2011) melakukan penelitian Tesis judul "Pengaruh Semen Terhadap Peningkatan
Kekuatan Tanah Sebagai Pondasi Perkerasan Jalan"

Dari hasil penelitian untuk perbaikan tanah dicampur dengan semen sangat berpengaruh dengan meningkatnya nilai $C B R_{100 \%}$ dari 8,30 $\%$ menjadi $C B R_{100 \%}$ maksimum $153,50 \%$ 
dengan kadar semen $12 \%$ dengan pemeraman 3 hari dan perendaman 4 hari.

b. Nugroho (2008), melakukan penelitian dengan judul : "Stabilisasi Tanah Gambut Rawapening dengan Menggunakan Campuran Portland Cement dan Gypsum Sintesis $\left(\mathrm{CaSO}_{42} \mathrm{H}_{2} \mathrm{O}\right)$ Ditinjau dari Nilai California Bearing Ratio $(C B R)$ ". Dari hasil penelitian laboratorium menunjukkan bahwa penambahan portland cement, gypsum sintetis dan masa pemeraman meningkatkan nilai $C B R$. Nilai $C B R$ yang dihasilkan mengalami kenaikan dan mencapai nilai maksimum pada kadar portland cement $5 \%$ dan gypsum sintetis $15 \%$ dengan masa pemeraman 7 hari yaitu sebesar $8,985 \%$. Nilai tersebut mengalami kenaikan hampir 3 kali lipat dari nilai $C B R$ tanah gambut asli yaitu sebesar $3,559 \%$.

\section{METODE PENGUJIAN}

\section{Tahapan Pengujian}

Pengujian dilakukan terhadap tanah lokal (existing) dalam kondisi terganggu (disturbed). Tahapan pengujian dilaksanakan sesuai dengan bagan alir seperti pada Gambar 3.1 berikut :
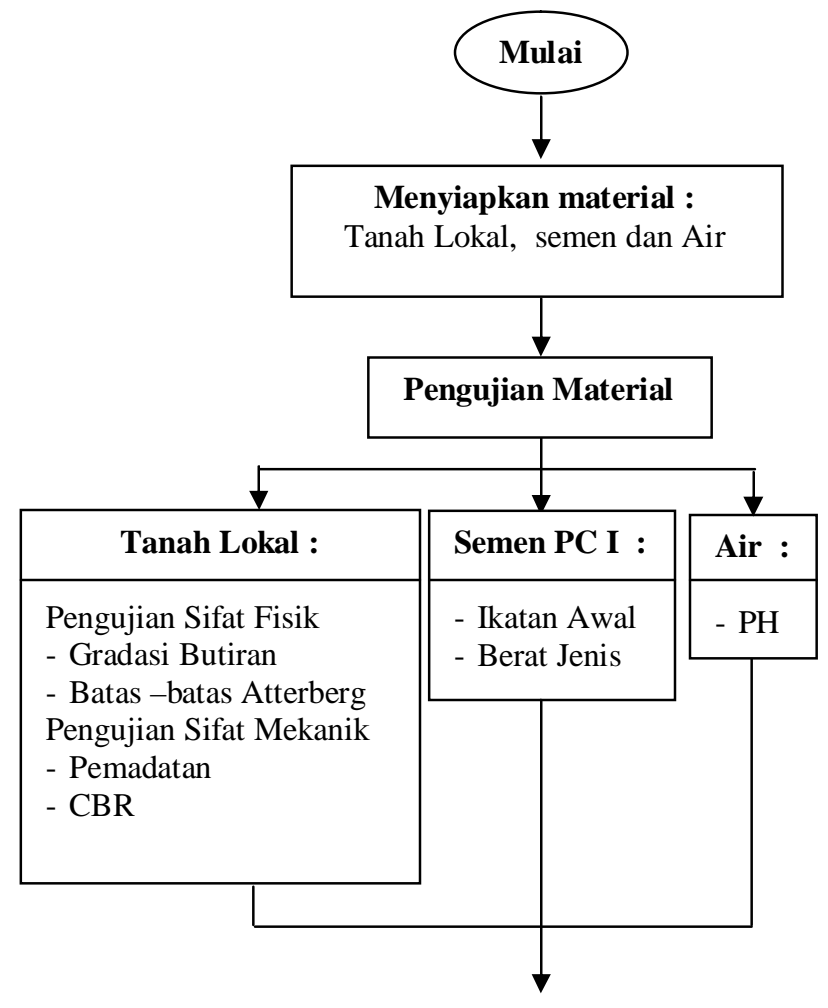

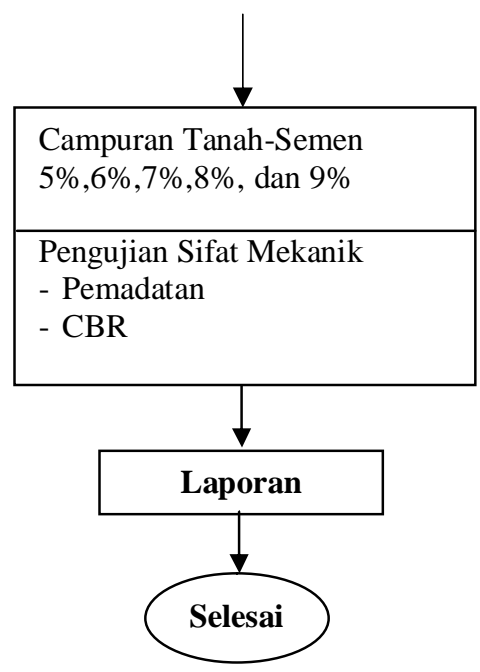

Gambar 3.1 Diagram Alir Tahapan Pengujian

\section{HASIL DAN PEMBAHASAN}

Dalam makalah ini mengulas tentang lapis pondasi tanah semen yang sudah distabilisasi dengan semen kadar semen 5\%,6\%,7\%,8\% dan $9 \%$ dengan pengujian sifat fisik dan mekanik di laboratorium.

\section{Hasil Pengujian Material}

Semen

Semen yang digunakan tipe I merk Tonasa dengan hasil uji berat jenis diperoleh 3,12 gr/cc dan menurut Suci Wulandari Indah Pratama dkk, ikatan awal 45 menit dan ikatan akhir 375 menit dari hasil pengujian Vicat.

Air

Air yang digunakan adalah air dari PDAM dengan hasil uji PH 5,10, berdasarkan SNI 033438-1994 (PH 4,5 - 8,5) memenuhi syarat untuk digunakan dalam Lapis Pondasi Tanah Semen.

Tanah Lokal

Pengujian dilakukan terhadap tanah yang diambil di quarry Dusun Mayawang, Timpah, pada ruas jalan Lungkuh Layang - Buntok dalam kondisi terganggu (disturbed). Pengujian yang dilakukan ini dibagi menjadi 2 (dua) kelompok utama yaitu uji sifat fisik dan sifat mekanis tanah.

\section{A. Hasil Uji Sifat Fisik Tanah Lokal \\ - Analisa Saringan \\ Gradasi ukuran butir material tanah lokal sangat penting dan salah satu faktor yang}


mempengaruhi terhadapat kekuatan. Berdasarkan hasil analisis uji distribusi ukuran butir diplot dalam satu grafik logaritmik terlihat tren persentasi dari ukuran butir material yang seperti pada Gambar 3.1 berikut :

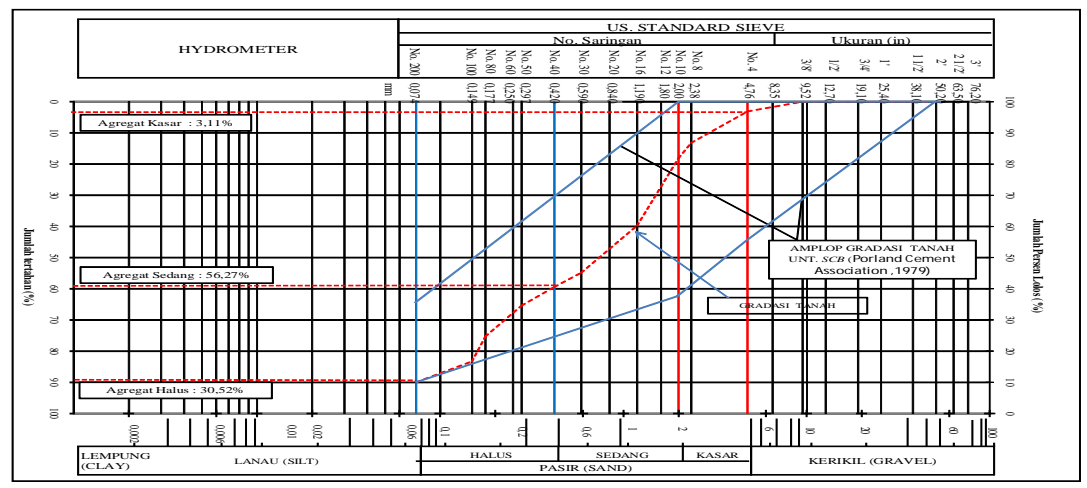

Gambar 3.1 Hasil Uji Distribusi Ukuran Butir Material Tanah Lokal

Dari hasil pengujian distribusi ukuran butir yang dapat dilihat pada Gambar 3.1 menunjukan material untuk pekerjaan Lapis Pondasi Tanah Semen memenuhi persyaratan yang di ijinkan (Porland Cement Association ,1979), dengan komposisi ukuran butiran adalah sebagai berikut :
- Agregat Kasar
$=3,11 \%$
- Agregat Sedang
$=56,27 \%$
- Agregat Halus
$=30,52 \%$
$=20,42 \%$
Tertahan \# 200
$=10,10 \%$

- Batas-batas Atterberg

Dari analisis pengujian batas-batas Atterberg material tanah lokal yaitu hasil dari pengujian Batas Cair diplot dalam grafik didapat hasil seperti Gambar 3.2 sebagai berikut :

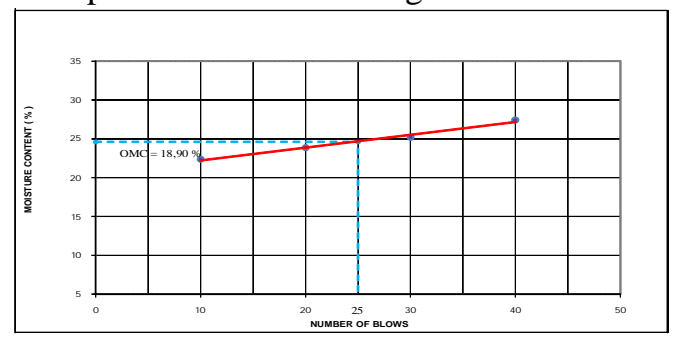

Gambar 3.2 Hasil Pengujian Batas Cair Material Tanah Lokal

Menurut batas-batas Atterberg Tanah Lokal ini termasuk golongan plastisitas rendah karena Plasticity Index $(P I) 6,21 \% \leq 10 \%$ syarat yang ditentukan (Hicks 2002).

Klasifikasi Tanah Sistem USCS berdasarkan hasil batas cair $(L L)$ dan indeks plastisitas $(P I)$, yang diplotkan dengan diagram plastisitas, termasuk pada kelompok $C L-M L$ yaitu lanau tak organik, lempung kepasiran dengan plastisitas rendah dapat dilihat pada Gambar 3.3 berikut :

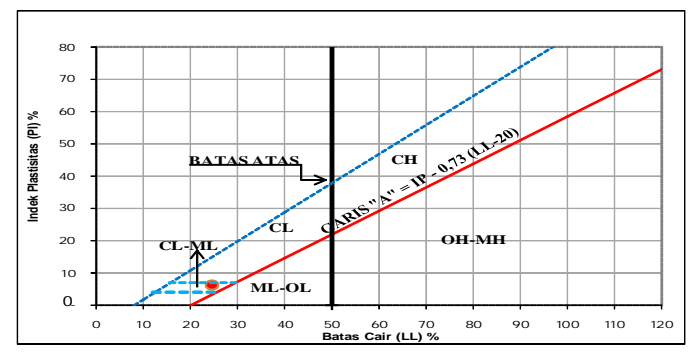

Sumber : Hendarsin (2000)

Gambar 3.3 Diagram Plastisitas Tanah Berbutir Halus Sistem USCS

Berdasarkan Klasifikasi Tanah Sistem AASHTO dan hasil pengujian batas cair $(L L)$ serta indek plastisitas $(P I)$, yang diplotkan dengan diagram plastisitas, termasuk pada kelompok $A-4$ yaitu lempung lanau dengan plastisitas rendah dapat dilihat pada Gambar 3.4 berikut :

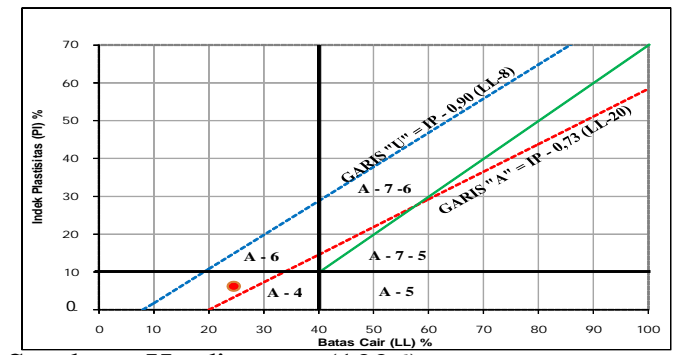

Sumber : Hardiyatmo (1996)

Gambar 3.4 Nilai-nilai Batas-Batas Atterberg untuk Subkelompok A-4, A-5,A-6 dan A-7 


\section{B. Hasil Uji Sifat Mekanik Tanah Lokal}

\section{- Uji Pemadatan Ringan}

Hasil uji pemadatan ringan (standart) tanah lokal dapat diplotkan dalam satu grafik hubungan antara berat isi kering maksimum $\left(\gamma_{\text {dmax }}\right)$ dan kadar air optimum $\left(W_{\text {opt }}\right)$ seperti pada Gambar 3.5 berikut:

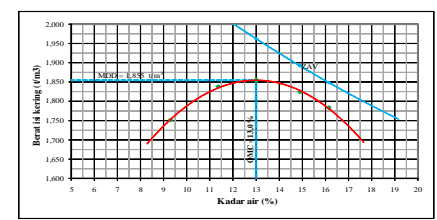

Gambar 3.5 Hubungan Kadar Air dengan Berat Isi Kering
Dari hasil pada Gambar 3.5 didapat berat isi kering maksimum $\left(\gamma_{\mathrm{dmax}}\right) \quad 1,855\left(\mathrm{t} / \mathrm{m}^{3}\right)$ dan kadar air optimum $\left(\mathrm{W}_{\mathrm{opt}}\right) 13,0 \%$.

\section{- Uji CBR Laboratorium}

Hasil uji CBR tanah lokal dan pemadatan standar hubungan antara kedua pengujian tesebut diplotkan dalam grafik yang akan menghasil nilai CBR ${ }_{100}$ adalah $9,40 \%$ dan $C B R{ }_{95}$ adalah $5,20 \%$ seperti pada Gambar 3.6 berikut :
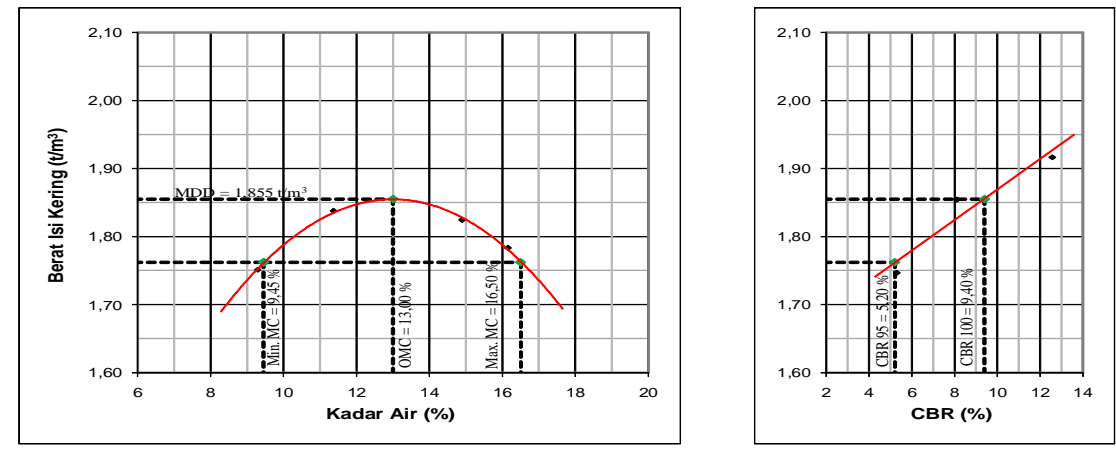

Gambar 3.6 Hubungan Hasil Uji Pemadatan dan $C B R$ Tanah

\section{Pengaruh Semen Terhadap Tanah Lokal}

a. Uji Pemadatan Berat
Hasil - hasil pengujian pemadatan ringan terhadap lapis pondasi tanah semen dapat dilihat pada Tabel 3.1 sebagai berikut :

Tabel 3.1 Hasil Pengujian Pemadatan Ringan Lapis Pondasi Tanah Semen

\begin{tabular}{|l|c|c|c|c|c|}
\hline \multirow{2}{*}{ Pengujian } & \multicolumn{5}{|c|}{ Sampel } \\
\cline { 2 - 6 } & \multicolumn{5}{|c|}{ Persentasi Semen Terhadap Berat Kering } \\
\cline { 2 - 6 } & $5 \%$ & $6 \%$ & $7 \%$ & $8 \%$ & $9 \%$ \\
\hline \multirow{2}{*}{$\begin{array}{l}\text { Berat isi kering }\left(\mathrm{t} / \mathrm{m}^{3}\right) \\
\text { Kadar air optimum }(\%)\end{array}$} & 1,858 & 1,860 & 1,863 & 1,872 & 1,883 \\
& 12,50 & 11,80 & 11,60 & 11,50 & 11,00 \\
\hline
\end{tabular}

Dari Tabel 3.1 hasil uji pemadatan ringan dengan kadar semen yang bervariasi dapat diplotkan dalam satu grafik hubungan antara kadar air dengan berat isi kering didapat seperti pada Gambar 3.7 berikut :

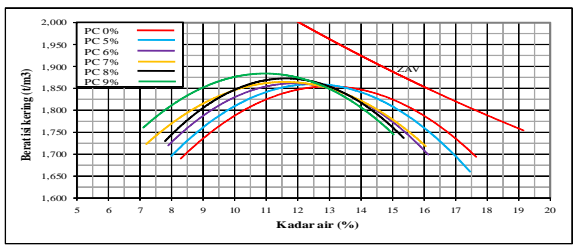

Gambar 3.7 Hubungan Kadar Air dengan Berat Isi Kering
Dari Gambar 3.7 dapat disimpulkan peningkatan berat isi kering maksimum $\left(\gamma_{d \max }\right)$ dari tanah lokal $1,855 \mathrm{t} / \mathrm{m}^{3}$, setelah distabilisasi dengan semen meningkat menjadi menjadi $\gamma_{\text {dmax }} 1,858 \mathrm{t} / \mathrm{m}^{3}$, $1,860 \mathrm{t} / \mathrm{m}^{3}, 1,863 \mathrm{t} / \mathrm{m}^{3}, 1,872 \mathrm{t} / \mathrm{m}^{3}$ dan $1,883 \mathrm{t} / \mathrm{m}^{3}$, seiring dengan bertambahnya kadar semen.

Dari Tabel 3.5 hasil uji pemadatan ringan dengan kadar semen yang bervariasi dapat diplotkan dalam satu grafik hubungan antara kadar semen dengan kadar air optimum didapat seperti pada Gambar 3.8 berikut : 


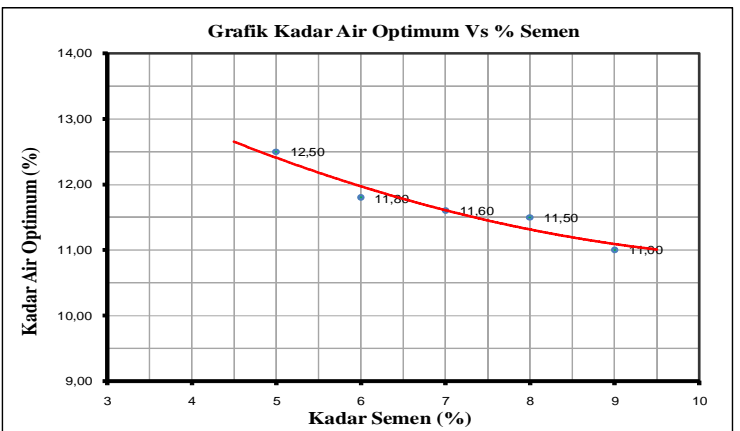

Gambar 3.8 Hubungan Kadar Semen dengan Kadar Air Optimum

Dari Gambar 3.8 dapat disimpulkan bahwa penurunan kadar air optimum $\left(W_{\text {opt }}\right)$ dari tanah lokal $13,0 \%$ menjadi $W_{\text {opt }} 12,5 \%, 11,8 \%, 11,6 \%$, $11,5 \%$, dan $11,0 \%$, seiring dengan bertambahnya kadar semen.
Peningkatan berat isi keringnya $\left(\gamma_{\text {dmax }}\right)$ dan/atau menurunkan kadar air optimum $\left(W_{\text {opt }}\right)$ dari tanah dikarenakan pengaruh penambahan semen yang mengisi rongga pori tanah, pada saat kondisi tanah berisi air dan udara. Akibat adanya penambahan semen yang mengisi dalam rongga pori tanah, persentasi air yang dikandung tanah menjadi berkurang. Peningkatan partikel padat (semen) berdampak pada peningkatan berat isi keringnya dibandingkan pada kondisi tanah semula.

\section{b. Uji $C B R$ Laboratorium}

Hasil - hasil pengujian CBR terhadap lapis pondasi tanah semen pada Tabel 3.2 sebagai berikut :

Tabel 3.2 Hasil Pengujian CBR Lapis Pondasi Tanag Semen

\begin{tabular}{|lc|c|c|c|c|c|}
\hline \multirow{3}{*}{ Pengujian } & \multicolumn{5}{|c|}{ Sampel } \\
\cline { 3 - 7 } & \multicolumn{4}{|c|}{ Persentasi Semen Terhadap Berat Kering } \\
\cline { 2 - 6 } & $5 \%$ & $6 \%$ & $7 \%$ & $8 \%$ & $9 \%$ \\
\hline \hline \multirow{2}{*}{ CBR $_{100}(\%)$} & 99,03 & 111,07 & 119,10 & 127,13 & 133,87 \\
\hline
\end{tabular}

Dari Tabel 3.6 hasil uji CBR dengan kadar semen yang bervariasi dapat diplotkan dalam satu grafik hubungan antara kadar air dengan berat isi kering didapat seperti pada Gambar 3.9 berikut:

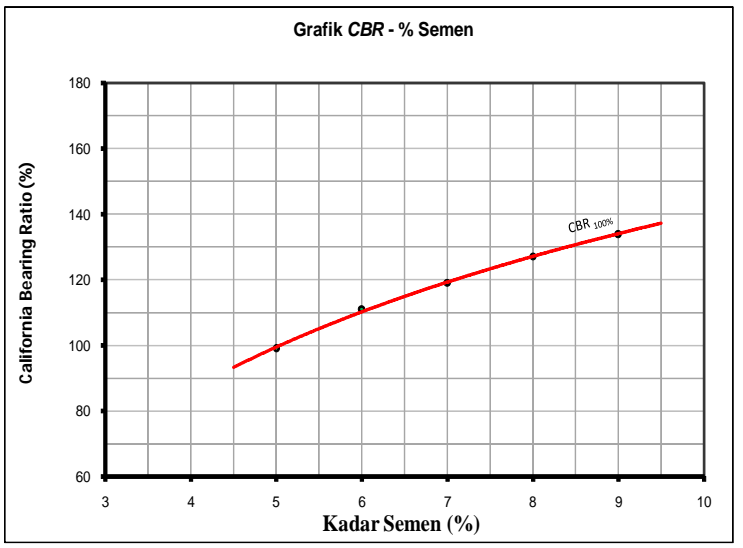

Gambar 3.9 Hubungan Kadar Semen dengan $C B R$

Dari Gambar 3.9 dapat disimpulkan peningkatan $C B R_{100 \%}$ dari tanah lokal $9,40 \%$, setelah distabilisasi dengan semen meningkat menjadi menjadi 99,03\%, 111,07\%, 119,10\% , $127,13 \%$, dan $133,87 \%$, seiring dengan bertambahnya kadar semen. Kekuatan daya dukung $\left(C B R_{100 \%}\right)$ bertambah karena rongga pori tanah seluruh atau sebagian besar terisi oleh pasta semen dan partikel-partikel tanah secara meluas, terikat oleh semen pada titik-titik kontak yang menyebabkan butiran saling bersinggungan dan rongga porinya semakin kecil, maka semakin besar aksi sementasi semakin besar pula kekuatan campuran tanah-semen.

\section{Kadar Semen Optimum Lapis Pondasi Tanah Semen}

Salah satu tujuan dari penelitian ini, untuk mengetahui kontribusi semen terhadap parameterparameter daya dukung $(C B R)$ untuk meningkatakan mutu tanah lokal agar bisa digunakan sebagai lapis pondasi perkerasan yang ideal sesuai dengan syarat-syarat spesifikasi teknik atau referensi yang ada. Berdasarkan hal tersebut di atas dan hasil penelitian di laboratorium, kadar semen optimum $\left(P C_{\text {opt }}\right)$ yang digunakan terhadap nilai $C B R$ seperti pada Gambar 3.10 sebagai berikut: 


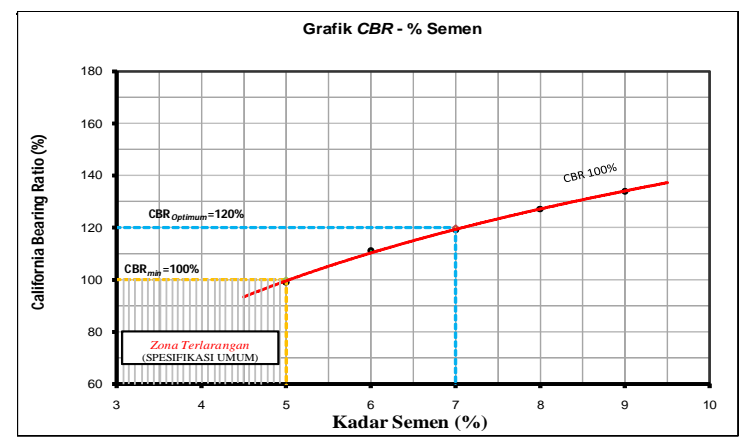

Gambar 3.10 Hubungan Kadar Semen dengan Kadar Air Optimum

Berdasarkan hasil pengeplotan pada Gambar 4.15 didapat nilai $C B R_{\operatorname{Min}} 100 \%$ dengan $P C_{\text {Opt }} \quad 5 \%$ dan nilai target $C B R_{\text {optimum }} 120 \%$ (Spesifikasi Umum 2010, revisi 3) dengan $P C_{o p t}$ $7 \%$, umur pemeraman 3 hari dan perendaman 4 hari.

Dengan $P C_{\text {Min }} 5 \%$ dan $P C_{o p t} 7 \%$, maka didapat $\gamma_{\text {dmax }} 1,859 \mathrm{t} / \mathrm{m}^{3}$ dan $\gamma_{\text {dmax }} 1,864 \mathrm{t} / \mathrm{m}^{3}$ seperti pada Gambar 3.11 berikut:

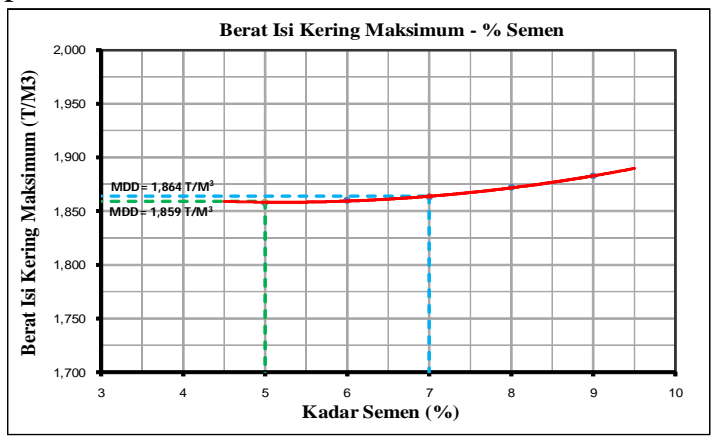

Gambar 3.11 Hubungan Kadar Semen dengan Berat Isi Kering Maksimum

Dengan $P C_{M i n} 5 \%$ dan $P C_{\text {opt }} 7 \%$, maka didapat kadar air seperti pada Gambar 4.12 berikut:

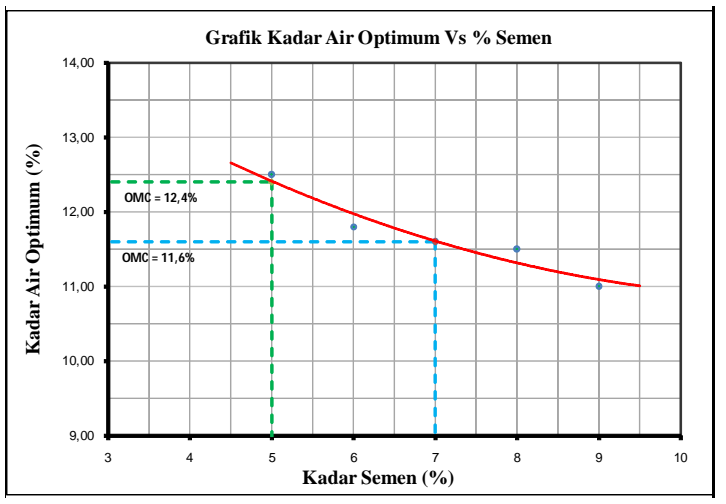

Gambar 3.12 Hubungan Kadar Semen dengan Kadar Air Optimum
Berdasarkan hasil pengeplotan pada Gambar 3.12 didapat nilai $W_{\text {opt }} 12,4 \%$ dan $11,6 \%$.

\section{PENUTUP}

\section{Kesimpulan}

Berdasarkan hasil analisis dalam penyusunan penelitian ini, maka dapat simpulkan antara lain :

1. Uji distribusi ukuran butir tanah lokal memenuhi syarat yang diijinkan untuk digunakan sebagai material stabilisasi tanah semen (Porland Cement Association ,1979).

2. Pengujian Batas-batas Atterberg tanah lokal memenuhi syarat yang diijinkan sebagai material stabilisasi tanah semen dengan indek plastisitas $6,21 \% \leq 10 \%$ syarat yang ditentukan (Hicks, 2002) dan klasifikasi tanah sistem USCS termasuk pada kelompok $C L-M L$ yaitu lanau tak organik, lempung kepasiran dengan plastisitas rendah dan AASHTO termasuk pada kelompok $A-4$ yaitu lempung lanau dengan plastisitas rendah.

3. Berat isi kering maksimum $\left(\gamma_{d \max }\right)$ tanah lokal $1,855 \mathrm{t} / \mathrm{m}^{3}$, kadar air optimum $\left(W_{\text {opt }}\right) 13,0 \%$ dan selama pelaksanaan didapat $\gamma_{\text {dmax }} 2,130$ $\mathrm{t} / \mathrm{m}^{3}$, dengan kadar air optimum $\left(W_{\text {opt }}\right) \quad 7,90 \%$ dan daya dukung $\left(C B R_{100}\right) 9,40 \%$.

4. Kadar semen optimum $\left(P C_{o p t}\right) 7 \%$, didapat nilai $C B R_{\text {optimum }} 120 \% \geq 120 \%$ nilai target yang disyarat (Spesifikasi Umum 2010, revisi 3), dengan berat isi kering maksimum $\gamma_{\text {dmax }} 1,864$ $\mathrm{t} / \mathrm{m}^{3}$ dan kadar air optimum $\left(W_{\text {opt }}\right) 11,60 \%$.

\section{Saran}

Berdasarkan kesimpulan dari penyusunan penelitian ini, maka di saran sebagai berikut:

1. Dianjurkan untuk lapis pondasi tanah semen material tanah yang ideal harus berbutir (laterit) atau tanah kepasiran dan sirtu ini lebih ekonomis ditinjau dari segi kadar semen.

2. Selama perawat (curing) sampel lapis pondasi tanah semen untuk pengujiam $C B R$ agar tidak terjadi penguapan air yang berlebihan harus benar-benar diperhatikan.

\section{DAFTAR PUSTAKA}

Badan Standar Nasional, 2008, Cara Uji Penentuan Kadar Air Untuk Tanah Dan 
Stabilitas Tanah Manyawang untuk.... Bambang. R

Batuan Dilaboratorium (SNI 1965-2008). Jakarta

Badan Standar Nasional, 2008, Cara Uji Penentuan Batas Cair Tanah (SNI 19672008). Jakarta

Badan Standar Nasional, 2008, Cara Uji Penentuan Batas Plastisitas dan Indeks Plastisitas Tanah (SNI 1966-2008). Jakarta

Badan Standar Nasional, 2008, Cara Uji Analisis Butir Tanah (SNI 3423-2008). Jakarta

Badan Standar Nasional, 2009, Cara Uji Kepadatan Ringan Untuk Tanah (SNI 031742-1989). Jakarta

Badan Standar Nasional, 1989, Metode Pengujian CBR Laboratorium (SNI 03-1744-1989). Jakarta

Badan Standar Nasional, 1994, Tata Cara Pembuatan Stabilisasi Tanah Dengan Semen Portland Untuk Jalan (SNI 03-34381994). Jakarta

Badan Standar Nasional, 2002, Metode Pengujian Hubungan Antara Kadar Air Dan Kepadatan Pada Campuran Tanah-Semen (SNI 03-6886-2002). Jakarta

Das, 2008, Advanced Soil Mechanics. Third Edition. Publishing by Taylor \& Francis. New York, U.S.A

Hardiyatmo, H.C, 2010, Stabilisasi Tanah Untuk Perkerasan Jalan, Gajah Mada University Press, Yogyakarta.

Hardiyatmo, HC, 2006, Mekanika Tanah 1, Edisi Keempat, Gajah Mada University Press, Yogyakarta.

Hendarsin, 2000, Perencanaan Teknik Jalan Raya. Penerbit Politeknik Negeri Bandung

Kementerian Pekerjaan Umum, 2006, Manual Konstruksi dan Bangunan Lapis Pondasi Tanah Semen

Nugroho, 2008, Stabilisasi Tanah Gambut Rawapening Dengan Menggunakan Campuran Portland Cement Dan Gypsum Sintesis (CaSO42H2O) Ditinjau Dari Nlai California Bearing Ratio (CBR). Jurnal
Teknik Sipil \& Perencanaan UNNES. Nomor 2 vol. 10 Juli 2008 Hal. 161-170

R, Bambang, 2011, Pengaruh Semen Terhadap Peningkatan Kekuatan Tanah Sebagai Pondasi Perkerasan Jalan, Tesis Program Pasca Sarjana Teknik Sipil Universitas Lambung Mangkurat Banjarmasin

Saodang H, 2005, Konstruksi Jalan Raya, Nova, Bandung

Pusat Litbang Prasarana Transportasi Badan Penelitian dan Pengembangan Kementerian Pekerjaan Umum, 2014, Spesifikasi Umum 2010 revisi 3. Jakarta 